\title{
The Challenges of Using E-Learning Platform amid Covid-19 Outbreak: Voices from the Lecturers
}

\author{
Sukma Septian Nasution ${ }^{1}$, Tryana ${ }^{2}$, Setiana Sri Wahyuni br. Sitepu ${ }^{3}$, Eka Margianti \\ Sagimin $^{4}$, Mohammad Fajar Mediyawan Gintings ${ }^{5}$ \\ Universitas Pamulang \\ dosen02032@unpam.ac.id'1 dosen00421@unpam.ac.id², dosen01057@unpam.ac.id², \\ dosen00481@unpam.ac.id ${ }^{4}$, dosen02556@unpam.ac.id
}

\begin{abstract}
When instructional process has been totally shifted to distance learning due to Covid-19 outbreak, challenges appear. This study aims at (1) identifying challenges lecturers of English department in a university in Indonesia are facing in preparing, conducting, and evaluating instructional practices using the institution's owned virtual learning platform and (2) revealing the lecturers' perspectives on each challenge. Addressing a set of questionnaire to 26 respondents from the study program as well as a semi- structured interview, this qualitative study reveals that challenges that the respondents face are consecutively ranked as (1) assessment, (2) dealing with students, (3) time management, (4) instructional process, (5) pressure, and (6) technology mastery. This study ends with a recommendation to gauge and improve quality-education assurance in implementing the distance instructional practices.
\end{abstract}

Keywords: E-Learning, Instructional Challenges, Perspectives

\section{Introduction}

As it is to almost all aspects of human life, disruption caused by the pandemic spread of Novel Coronavirus to education is inevitable. All higher education institutions have responded by temporal closure from any social interaction and instructed their faculty members to run distance instruction to mitigate the impact. Accordingly, platforms to accommodate the rapid innovation in instructional process are progressively optimized thanks to the advance of digital technology. However, transforming the instructional system may potentially cause issues to all parties involved (Marinoni, Land \& Jensen, 2020) because this spontaneous policy does not come with enough scientific evidence in quality-education assurance and is lack of gauging challenges faced by educators.

Educators do not anticipate reliance on technology that replaces their position as dispensers of knowledge and urges them to be facilitators, mentors and motivators at the same time to inspire their students (Onyema \& Deborah, 2019). Not to mention there are some external factors like financial costs, regulations, digital gap, and cultural leap educators have to also face (Amemado, 2020). These might challenge them to run the instructional process in a full semester.

Unfortunately, this confinement leaves educators no other option than digital technology to conduct their classes as a commitment to avoid cluster contagion in institution. One of popular digital technologies is e-learning. This is a digital platform which facilitates teachers and students to communicate, and exchange information virtually. This platform is multimodal that optimizes the use of internet and internet- based sources as source of learning. It allows users to fruitfully gather knowledge and education both by synchronous and asynchronous 
methodologies (N.D., Salleh, Lahad, 2012) with its flexibility, portability, higher retention, greater collaboration, reduced overall cost, and consistency in delivery (Agariya, \& Singh, 2012).

With all its advantages, full commitment to e-learning as a learning platform, in contrast, has forced massive adaptation and strongly impact educator' livess. Higher education institutions are confronted with a new system which demands them to adapt. In short, working from home, dealing with technology, corresponding with students and adapting teaching process distantly have changed their life. This change is also faced by educators in a private university in Indonesia. Since the midst of March, 2020, the institution, adhered to the government's instruction, has closed the university from classroom-situated instruction and totally moved to its legally-owned e-learning platform as shown in Figure 1.

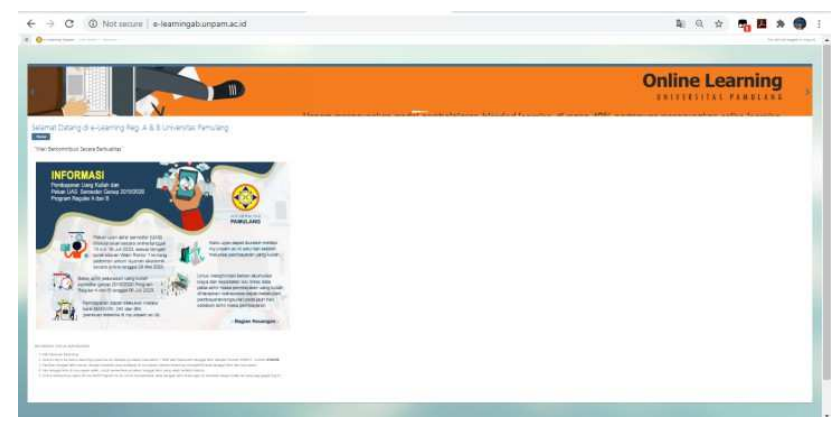

Fig.1. The Institution's E-learning Home Page

Every lecturer in the university is obliged but not limited to conduct instructional process for all subjects in this forum with some compulsory activities attached to it. The platform is multimedia that it allows lecturers and students to post written, audio, visual, or even videobased participatory messages in one forum. The policy mentions that this takes a whole semester and even year as a commitment to combat the outbreak of covid-19 disease in the institution. This implementation potentially challenges the lecturers in many aspects. Accordingly, without ignoring students' perspectives, this paper aims at exploring the lecturers' challenges towards the implementation of instructional activities via the e-learning platform amid the Covid-19 outbreak.

Researches on the effects of online learning due to the pandemic during the current situation have been largely investigated. The recent cases become the most alarming issue since this pandemic mostly happens in many countries. Onyema, Eucheria, Obafemi, Sen, Atonye, Sharma \& Alsayed (2020) discussed Covid-19's effect on education. They gathered primary information through standardized questionnaires given to 200 respondents, which consisted of selected teachers, students, parents, and policymakers from different countries. Using STATA/Regression, the data obtained were analysed. The findings indicate that Covid19 has adverse effects on education, including delays in learning and decreased access to educational and research services, employment losses, and increased student debts. The results also indicated that during the Coronavirus pandemic, many educators and students relied on technology to ensure continued online learning. Nonetheless, online education has been disrupted by weak infrastructure, including network issues, power, inaccessibility, unavailability, and limited technical skills. The study highlights Covid-19's negative effects on the education sector, and the need for all educational institutions, educators and learners to embrace technology and develop their digital skills in line with changing global trends and 
educational realities.

Moreover, Allam, Hasan, Mohideen, Ramlan, and Kamal (2020) also investigated a survey on Online Distance Learning mode during the Covid-19 outbreak in Malaysia. The research has been conducted to measure the level of online distance learning readiness because of the positive carrier statistics published by Malaysia daily increase that requires government action to enforce control of the movement. The objective of the study expected to improve students' academic performance by enhancing computer/internet literacy competency (CIL), selfdirected learning (SDL), and motivation of learning (MOL). The movement control order (MCO) affects undergraduate students from the Faculty of Communication and Media Studies who are just beginning a new semester in week four to stay at home when learning activities continue to use online distance learning (ODL) mode. By using descriptive statistical analysis, this study found that CIL is at a high level among graduate students, while SDL and MOL recorded at a low level.

Similar to Allam et al., Mailizar, Almanthari, Maulina, and Bruce (2020), investigated the case of e-learning of secondary school of mathematics teachers on e- learning implementation during the pandemic in Indonesia. They focused on four hindrances level; teacher, school, curriculum, and student. Around 159 participants from lower and upper secondary schools in Indonesia are involved. The result demonstrated that student-level barriers had the highest impact on e-learning use, and it showed a strong positive correlation with the school level barrier and curriculum level barrier. The study showed that teachers' backgrounds did not affect the level of obstacles.

\section{The Challenges Using E-Learning Platform}

Amid the pandemic, education practitioners are insisted to not spin around what instructional method to use (Nasution \& Sukmawati, 2019) but to confront and adopt instructional medium from offline mode or face-to-face learning into online learning or a remote education. Just as many countries confronted, Indonesia has also adopted the teaching and learning process from offline mode or face-to-face learning into online learning or a remote education. This situation brought a challenging style for students and teachers in facing the new platform in education. Atmojo \& Nugroho (2020) investigated how EFL teachers carry out online EFL learning, including its challenges. They found many problem emerged from the students, the teachers, and parents. As a consequence, online learning does not run well due to a lack of preparation and planning.

Unlike those previous studies, Almuraqab (2020) reveals the university students' perspective, challenges, and attitudes towards distance learning during the lockdown. The result shows that $55 \%$ of students liked distance learning. Interestingly, the previous researches yielded a similar result. The Covid-19 outbreaks have the same impact on the existence of teaching and learning mode. To investigate contradictory evidence, we will bridge the missing gap in how English Literature lecturers encountered the challenges during the pandemic of Covid-19 into a distance learning or e-learning mode. 


\section{Method}

This is a qualitative study that explores the challenges encountered by English department lecturers of a university in Indonesia in fully practicing virtual instruction , particularly elearning platform, as an aftermath effect of novel corona virus outbreak. There are 26 respondents that equally represent age, gender, and subjects taught. The data were obtained from a set of questionnaire investigating the respondents' responses to some potential challenges they face during the virtual teaching practices. Findings from the questionnaire were validated by that of semi-structured interview aiming to delve their personal opinion on the institutional education-policy.

\section{Result and Discussion Assessment}

The analysis on assessment focuses on four aspects or main challenges, which are redesigning assessment into assignment (Q1), preventing plagiarism and cheating (Q2), and extra attention on formative assessment (Q3), and reorienting assessment (Q4). The findings reveal that most challenging part in shifting to full online mode of learning is to deter students from plagiarism and cheating (Q2) as can be seen on Figure below. It is followed by the challenges of putting extra attention to on-going assessment rather than summative assessment (Q3). The result can be seen in Figure 2.

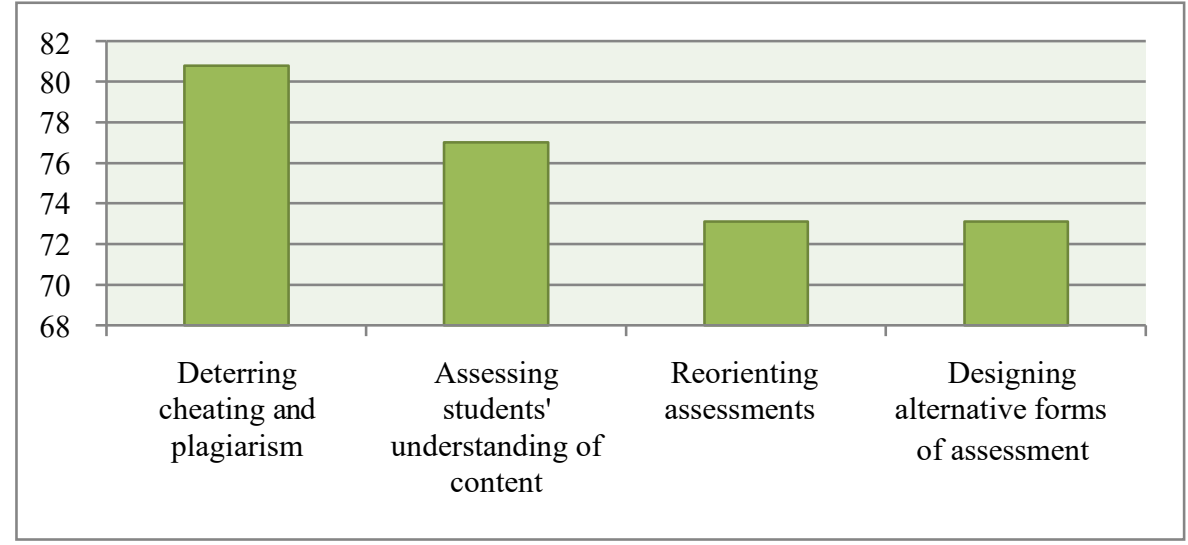

Fig.2. The Percentage of Challenges in Assessing Virtually

Needless to say, even in offline mode of learning, considerable concern and efforts are put to prevent plagiarism and cheating. During the switch to full online mode, the concern on plagiarism and cheating increase due to the feeling loss of control and inability to directly observe students in conducting assessment activities through online learning mode. This is shown in the extract from the lecturers below.

\subsection{Extract 1 Respondent 1}

I can't make sure whether the students do the assessment by himself or not. 


\subsection{Extract 2 Respondent 2}

Whatever the type of the assessment is, without direct monitoring by the teacher or lecturer, the validity of the students' work would not be $100 \%$ fulfilled. The concern on plagiarism and cheating results in burden on the lecturer to allocate extra time to check students' work on assessment. This can be seen from the following extracts.

\subsection{Extract 3 Respondent 3}

Checking the plagiarism on their tasks takes my time. The second challenge on the aspect of assessment is the requirement to intensify formative assessment. The main reason for this challenge is due to the distrust that also stems from the concern on plagiarism and cheating. In this sense, the lecturers must also shift the assessment of learning to a weekly basis to observe students' learning progress.

The last challenge in assessment is the obligation to redesign and reorient assessment to suit the condition of online learning. The lecturers feel that the challenge arise more from reorienting assessments in terms of schedule, formats, quantity, duration, and marking of projects. Meanwhile, lecturers are less concerned with redesigning assessment into an alternative form such as project, assignments, and portfolios.

\subsection{Extract 4 Respondent 4}

Especially for course like speaking, it is hard for me to asses them, via zoom it must be appropriate one, but it is costly for some students.

\subsection{Extract 5 Respondent 5}

In project-based assessment, they sometimes share unequal responsibility in preparing the project.

\section{a) Problems with Students}

The last but not least, challenges that the respondents have to face come from which they have to deal with students' problem in learning virtually as depicted by Figure 3. 


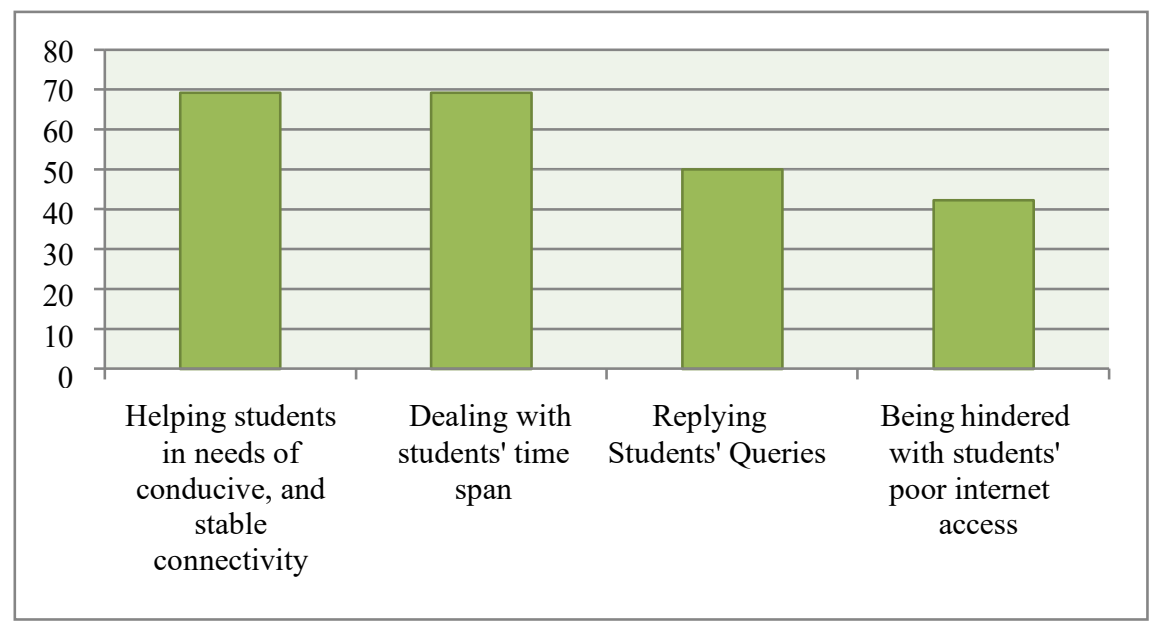

Fig.3. The Percentage of Challenges Dealing with Students

Figure 3 reveals that challenges also happen to the interaction within the lecturers and their students. $69.3 \%$ of the respondents cannot cope with their students' lack of connectivity due to signal issues. Many of the students dwell in remote area or have decided to return home located in rural area due to the outbreak. It causes them have limited access to connection. Elearning allows students to reply in the forum within certain days when they are available by time. The convention does not strict lecturers and students to meet in one time making it hard for the lecturers to respond the students' queries all along the days. It causes $69.3 \%$ of them consider students' time span in managing the instructional activities. This leads them to contain the activities that are potential to burden students' time. Another problem is $50 \%$ of the respondents cannot deal with replying their students' queries due to time constraints. All of these problems consequently hinder $42.3 \%$ of them in running the instructional process.

\subsection{Extract 6 Respondent 6}

Some students have no money for internet quota. Sometime they got free quota, however it is not enough to access platform like zoom. So they focus on campus e learning system only.

\subsection{Extract 7 Respondent 7}

Students may already be tired of the whole online learning process, so some classes have minimal attendance. Most of the students in the university are workers. It means that they do not rely on their parents for institutional tuition. Everything was normal before the pandemic. The pandemic, however, has caused some of them jobless. Some others have lower income than they were supposed to be. It brings burden to them when they have to spend money to purchase internet quota in order for them to virtually have access to the instructional practices. Some others live in hard-to-access area causing them find it hard to join internet-based learning practice. It is in line with Atmojo, and Nugroho (2020) that financial condition, unstable internet connection, and low digital literacy, students' punctuality with deadline, and students' various learning style are of some challenges teachers have to deal with when using virtual instructional practices. 


\section{a) Time Management}

Figure 4 displays the percentage of the respondents who face some challenges with practicing virtual instruction using the institution's e-learning platform.

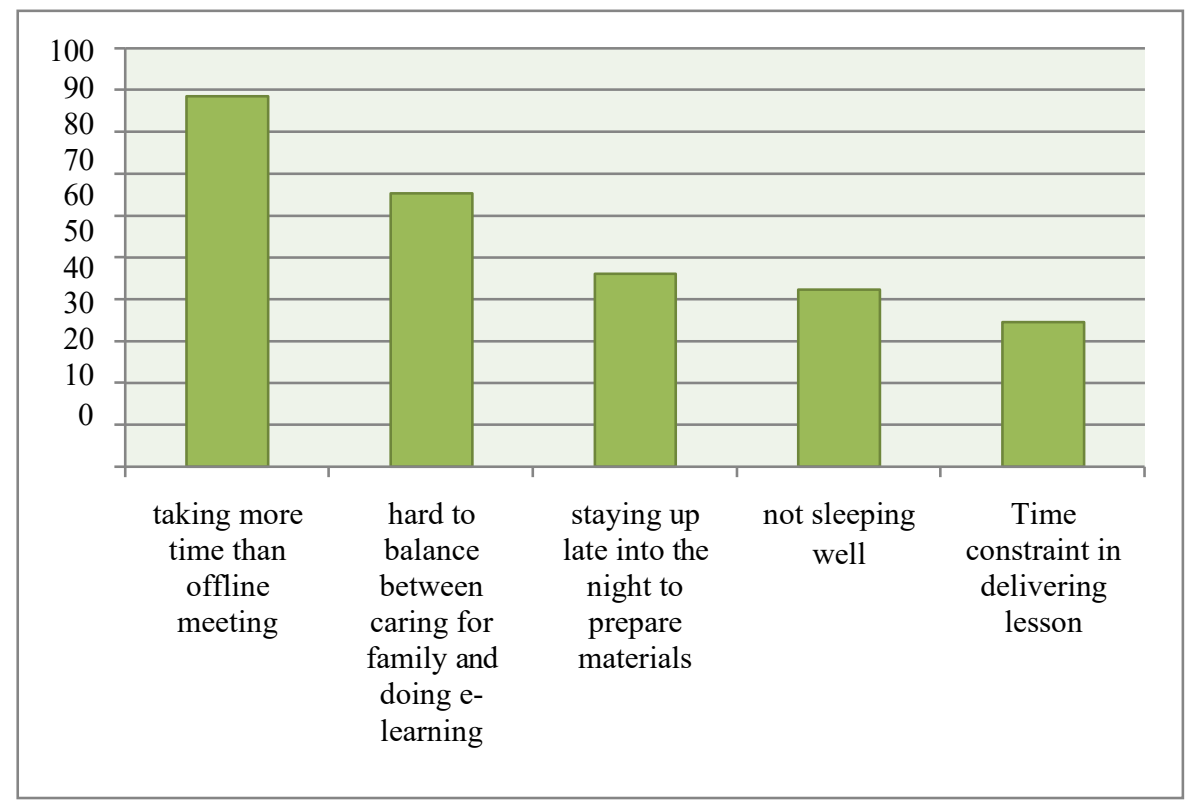

Fig.4. The Percentage of Challenges in Time Management

It is tangible that shifting to fully-virtual instructional practices gives some impacts towards the respondents. It is of time management they find it challenging. At around $88.5 \%$ believe that e-learning-based instruction spends their time more than the offline do. It means the virtual mode of e-learning was time-consuming for some lecturers. Further, they also find that balancing between caring for family and teaching from home is tough especially for young mothers. $46.2 \%$ of the respondents have to work longer to night to prepare teaching material. It causes $42.3 \%$ of them not sleep well. Another significant challenge is time constraint for a meeting.

\subsection{Extract 8 Respondent 8}

I slept only about 4 hours

\subsection{Extract 9 Respondent 9}

Since I have a baby, I have to wait to check my class till she falls asleep. I am happy to reply my students' comment but sometimes when I have more time to comment, there are only 2 or 3 replies from students so I have to remind them via WAG. Then many comments appear, at the same time, my baby wakes up. These statements are evident to the effect of the virtual practices towards the respondents' life pattern. E-learning is flexible by time but this flexibility makes uncertainty to how much time is exactly needed to accomplish one meeting. This uncertainty cannot correspond household activities some respondents who are also a mother 
and a wife have to confront with. This is in line with Krish (2008) that preparing online learning takes more time than preparing face-to-face class because it needs bigger investment to create proper design and implementation (Green,2016).

\section{a) Instructional Practices}

Some potential challenges in instructional practices are given to reveal how the respondents respond to each item which is depicted by Figure 5.

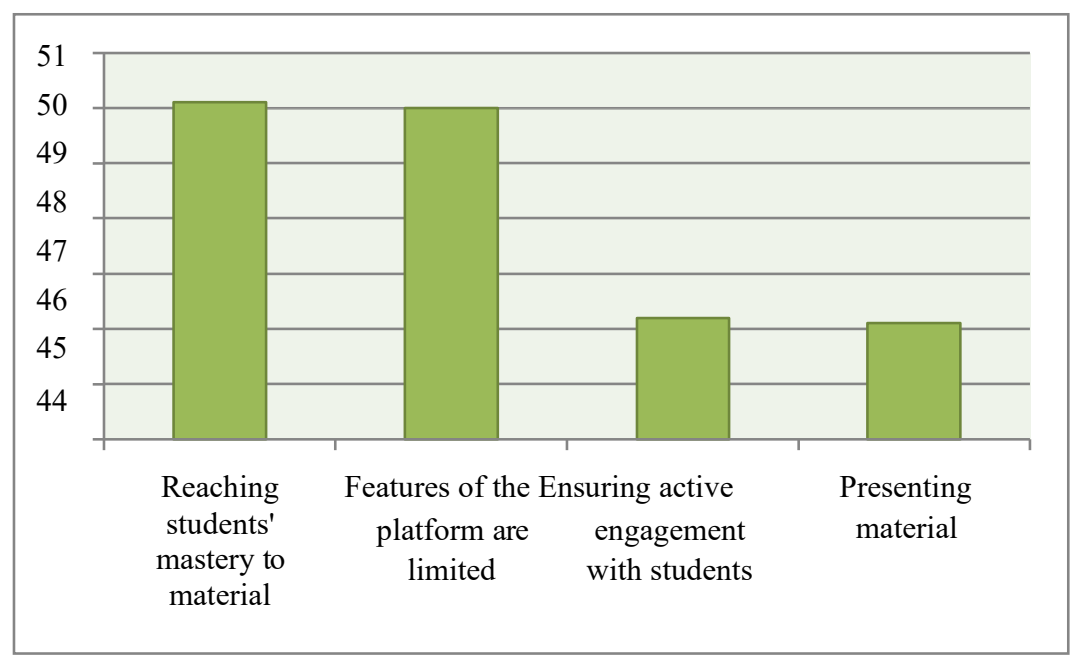

Fig.5. The Percentage of Challenges in Instructional Practices

Figure 5 proves that respondents also find it challenging to conduct quality instructional practices. $46.2 \%$ of the respondents believe that ensuring active interaction and engagement from students in their online class is tough. Fortunately, a half of the respondents find it not really challenging and only 1 respondent believe it is not of any issue at all. Further, almost a half of the respondents cannot reach whether their students understand materials they delivered. They also agree that delivering materials through e-learning is harder than it was in direct meeting. To overcome it, $50 \%$ of the respondents have to support the materials by additional tools like video which is time-consuming and costly for them.

\subsection{Extract 10 Respondent 10}

Not all students can be active in the e-learning. They seem lazy to read or to study, some only copy paste from others when answering questions.

\subsection{Extract 11 Respondent 11}

I am not familiar enough with the features in e-learning website. The low capacity size limit also makes it worse. I usually communicate with my students more by using social media group to give clearer instructions.

These extracts indicate that using e-learning platform is not enough to run effective instructional processes. The respondents eventually have to use other tools to support the 
instructional success which can engage their students more to improve their understanding towards the material presented. It is in line with Ruth (2018) that conducting distance learning has low faculty approval because most educators agree that it gives access to more students, but few agree that it helps students learn more effectively.

\section{a) Pressure}

Another challenge that is explored is towards the respondents' mentality in conducting the virtual classes. Figure 6 depicts pressure the respondents are facing.

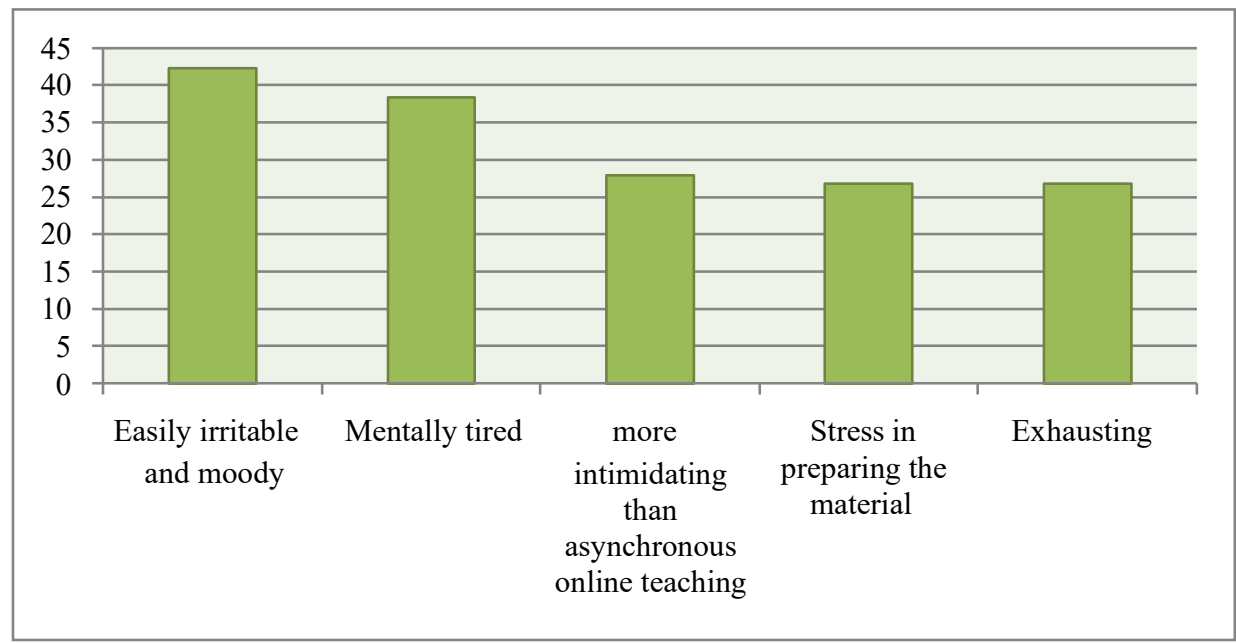

Fig.6. The Percentage of Pressure

That using e-learning is a mental burden for some lecturers is evident. It is shown by $38.4 \%$ of the respondents stating that they are mentally tired after classes. It is slightly smaller in percentage that they sometimes feel mentally-exhausted after all. This is caused by tough stages they have to pass through in preparing materials and conducting instructional practices. Further, it makes $42.3 \%$ of the respondents moody and easily irritable since starting the class for its exhausting series of meeting. Fortunately, it does not come to a statement that synchronous teaching more intimidating than asynchronous one.

\subsection{Extract 12 Respondent 12}

I have little kids and no maid to help me at home. So with prolonged duration of teaching at home with kids around is really tough to do.

\subsection{Extract 13 Respondent 13}

Managing my time as a mom and a lecturer sometimes is stressful. If I were in such condition, I should choose the priority to care my family in the first line of my life. I could do my responsibility as lecturer then. As a result, doing e learning is not burdensome.

Challenges in terms of pressure are not meant to delve the weaknesses of the platform for the respondents. It is believed that any kind of instructional activities have its challenges. This 
section is of evidence that needs to be taken into account that mental pressure improves when virtual practices are implemented.

\section{a) Technology Mastery}

The next aspect that is being delved into in this study is teachers' technology mastery. This aspect is divided into five challenges, which are bewilderment from different types of online learning platform $(\mathrm{Q} 1)$, hesitation on the use of technological tools $(\mathrm{Q} 2)$, struggle in learning an using instructional technology tools, doubt in self and low self-esteem (Q4), and challenge in combining both synchronous and asynchronous mode of online learning (Q5). The findings show that, in overall, technology mastery does not bear complication on the shift to full online learning mode as shown by Figure 7 below.

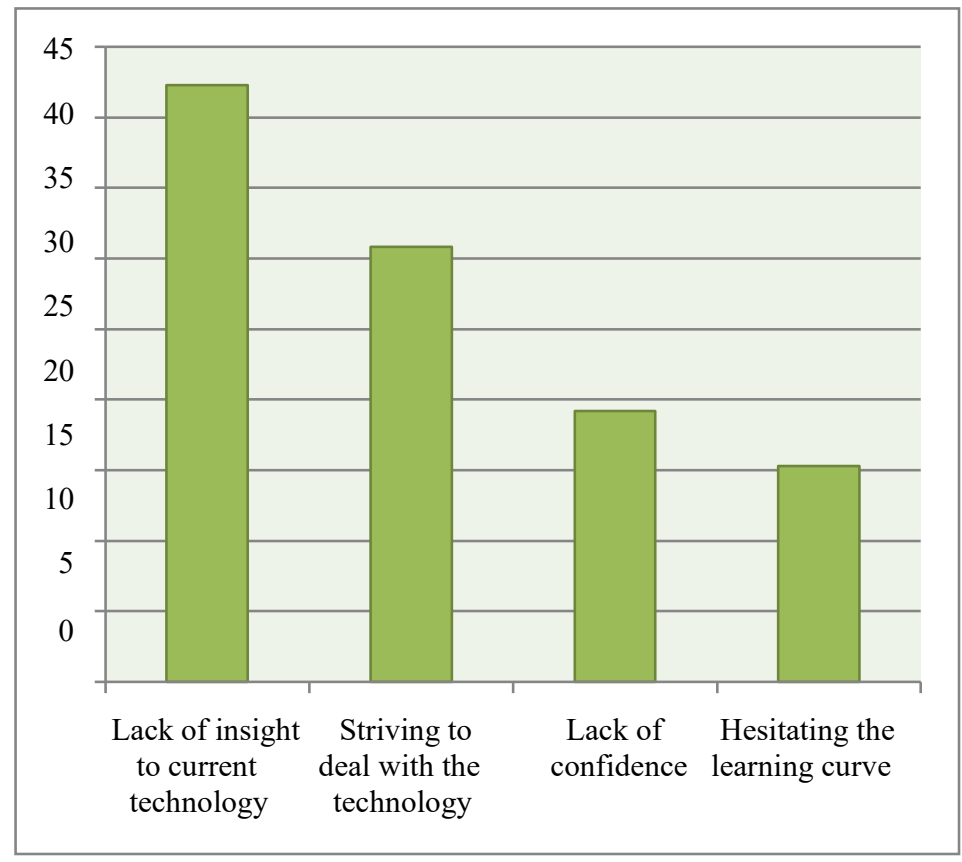

Fig.7. The Percentage of Challenges in Technology Mastery

The challenge encountered by lecturer on the aspect of technology mastery revolves around the tiredness from using multiple tools of online learning and combining the synchronous and asynchronous mode of online learning. The two problems are interrelated and stems from the urge of lecturers to deliver material successfully.

\subsection{Extract 14 Respondent 14}

There is obligation to use E-Learning campus system, however the system is not completed yet for video conference...it means that I have to use not only e learning campus system but also other platform like zoom, WhatsApp and other platforms. 


\subsection{Extract 15 Respondent 15}

My personal obstacle or challenge is integrating the e learning with another plat form or another technological product. As a result, I am applying screen recording to support and strengthen e-learning that leads the students obtain more comprehension.

The limitation of time given by the university results in confusion to the lecturers. Most of the lecturers think that asynchronous mode of online learning is not really effective due to the missing interactive delivery. However, with the short time given to conduct the online learning, lecturers are struggling to add a synchronous session of learning. Meanwhile, there is an obligation to conduct discussion forum on the university's learning management system where online learning activities are being monitored and supervised.

The lecturers view that the shift to full online learning rather as an opportunity for them to learn about educational technological tools. This is also due to the familiarity of the lecturers to online learning that is already implemented by the university before the time of pandemic. The university has already implemented a blended-learning approach to online learning although only for make-up classes. The positive response to technology mastery can be seen as shown by the extracts below.

\subsection{Extract 16 Respondent 16}

I have no problem with this since there is a lot of information provided by searching engine I can read and learn then implement in my class.

\subsection{Extract 21 Respondent 21}

It encourages me to learn more and more about technology.

\section{Conclusion}

Higher education institutions do not have other choices to run instructional practices but distance learning to support the government to combat the Covid-19 outbreak. Lecturers as the ones who run the practices, in fact, find it challenging to implement it. Challenges are subjective and cannot be overgeneralized when it is related to reasons. However, this study proves that challenges in implementing the internet-based instruction are related to assessment, dealing with students, time management, instructional process, pressure, and technology mastery.. This study is to limit the challenges faced only by respondents who teach in English department in a university in Indonesia. Accordingly, it is suggested that other researchers gauge the same study in their own community to authentically reveal what challenges the education practitioners are facing when using electronic or online learning. This study ends with a recommendation for stake holders of any institution to evaluate and empower current instruction system that potentially minimizes the challenges.

\section{References}

[1] Agariya, A.K., \& Singh, D. (2012). E-Learning quality: Scale development and validation in 
Indian context. Knowledge Management \& E-Learning: An International Journal. 4(4), 500-517.

[2] Allam, S. N. S., Hassan, M. S., Mohideen, R. S., Ramlan, A. F., \& Kamal, R. M. (2020). Online Distance Learning Readiness During Covid-19 Outbreak Among Undergraduate Students. International Journal of Academic Research in Business and Social Sciences, 10(5), 642-657.

[3] Amemado, D. (2020). Covid-19: An unexpected and unusual driver to online education. Research on Online International Higher Education. 12(2). 12-14.

[4] Atmojo, A. E. P., \& Nugroho, A. (2020). EFL classes must go online! teaching activities and challenges during Covid-19 pandemic in Indonesia. Register Journal, 13(1), 49-76. https://doi.org/10.18326/rgt.v13i1.49-76.

[5] Davidson, L.Y.Z., Richardson, M., \& Jones, D. (2014). Teachers' perspective on using technology as an instructional tool. Research in Higher Education Journal. 24(2). 1-25.

[6] Gómez-Rey, P., Barbera, E., \& Fernández-Navarro, F. (2016). Measuring teachers and learners' perceptions of the quality of their online learning experience. Distance Education, 37(2), 146163. https://doi.org/10.1080/01587919.2016.1184396

[7] Green, P. (2016). How to Succeed with Online Learning. In N. Rushby \& D. W. Surry (Eds.), The Wiley Handbook of Learning Technology (1st ed., pp. 261-286). https://doi.org/10.1002/9781118736494.ch15

[8] Krish, P. (2008). Language Learning in the Virtual World: Instructors' Voices. International Journal of Pedagogies and Learning, 4(4), 113-129. https://doi.org/10.5172/ijpl.4.4.113

[9] Mailizar, Almanthari, A., Maulina, S., \& Bruce, S. (2020). Secondary school mathematics teachers' views on e-learning implementation barriers during the COVID-19 pandemic: The case of Indonesia. Eurasia Journal of Mathematics, Science and Technology Education, 16(7). https://doi.org/10.29333/EJMSTE/8240

[10] Marinoni, G., Land, H.V., Jensen, T. (2020). The Impact of Covid-19 on Higher Education around the World: IAU Global Survey Report. Paris: International Association of Universities.

[11] Nasution S.S., \& Sukmawati, N.N. (2019). Model United Nations: Improving the Students' Speaking Skill. Journal of English Education Society. 4(2). 47-52. doi: 10.21070/jees.v4i2.2100

[12] N.D. Oye , M. Salleh, and N.A. Iaha. (2012). E-Learning Methodologies and Tools. International Journal of Advanced Computer Science and Applications. 3(2). 48- 52.

[13] Onyema, E.M., \& Deborah, E. C. (2019). Potentials of Mobile Technologies in Enhancing the Effectiveness of Inquiry-based learning. International Journal of Education (IJE), 2(1), 1-25. https://doi.org/10.5121/IJE.2019.1421

[14] O'Connell, J. (2016). Networked participatory online learning design and challenges for academic integrity in higher education. International Journal for Educational Integrity, 12(1). https://doi.org/10.1007/s40979-016-0009-7

[15] Ruth, S. (2018). Faculty Opposition to Online Learning: Challenges and Opportunities. International Journal of Technology in Teaching and Learning, 14(1), 12-23.

[16] Saif Almuraqab, N. A. (2020). Shall universities at the UAE continue distance learning after the CoviD-19 pandemic? Revealing students' perspective. International Journal of Advanced Research in Engineering and Technology, 11(5), 226-233. https://doi.org/10.34218/IJARET.11.5.2020.024

[17] Zahara., Kirilova, G.I., \& Windarti, A. (2020). Impact of Corona Virus Outbreak Towards Teaching and Learning Activities in Indonesia. SALAM; Jurnal Sosial \& Budaya Syar-i. Vol. 7 No. 3 (2020), pp.269-282, 